\section{Commentary: The promise of precision cardiovascular surgery}

\author{
Imtiaz Ali, MD, and \\ Paul W. M. Fedak, MD, PhD, FRCS(C)
}

Since being first described by Dor and colleagues, ${ }^{1}$ surgical ventricular reconstruction (SVR) for the treatment of ischemic heart failure has accrued immense clinical experience. ${ }^{2,3}$ Often performed in conjunction with coronary revascularization, SVR aims to reduce left ventricular volumes and reshape the ventricular cavity to a more physiological ellipsoid geometry to restore heart performance.

The worldwide experience shows that SVR increases ejection fraction and reduces left ventricle size. The effects of restoring a more favorable ellipsoid geometry are less consistent, with some studies reporting an increased sphericity index following SVR. ${ }^{4}$ Importantly, the influence of SVR on diastolic function remains poorly understood. Some experts attribute a documented lack of clinical effectiveness to a maladaptive change in the end-diastolic pressure-volume relationship that negates any improvements in systolic function. ${ }^{5}$

In this issue of the Journal, Fantini and colleagues ${ }^{6}$ examine a small series of ischemic patients with preexisting severe diastolic dysfunction who underwent SVR. The patients had a restrictive filling pattern (RFP) on echocardiographic examination, as evidenced by an E/A ratio $>2$. These surgeons are highly experienced with SVR. The effects of SVR on RFP (diastolic function) was examined using serial postoperative echocardiography. At discharge, approximately one-half of the patients had improved RFP, whereas the remaining patients showed no change in RFP. By 7 months of follow-up, those with improved RFP also had symptomatic benefits; however, no late differences in major adverse cardiovascular events or event-free survival were observed.

\footnotetext{
From the Section of Cardiac Surgery, Department of Cardiac Sciences, Cumming School of Medicine, University of Calgary, Libin Cardiovascular Institute, Calgary, Alberta, Canada.

Disclosures: Authors have nothing to disclose with regard to commercial support. Received for publication Oct 27, 2019; revisions received Oct 27, 2019; accepted for publication Oct 28, 2019; available ahead of print Nov 21, 2019.

Address for reprints: Paul W.M. Fedak, MD, PhD, FRCS(C), C880, 1403-29 St NW, Calgary, Alberta, Canada, T2N 2T9 (E-mail: paul.fedak@gmail.com).

J Thorac Cardiovasc Surg 2021;161:661-2

$0022-5223 / \$ 36.00$

Copyright (c) 2019 by The American Association for Thoracic Surgery

https://doi.org/10.1016/j.jtcvs.2019.10.176
}

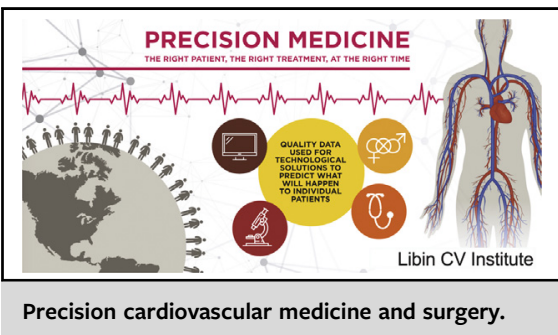

CENTRAL MESSAGE

Surgery to restore ventricular shape, size, and function may require more precision to determine which specific patients may benefit and when surgery should be optimally performed.

Greater relative wall thickness was associated with improved RFP following SVR. Wall thickness may be a surrogate marker of myocardial viability. More advanced imaging for myocardial viability as well as size, shape, and function using cardiac magnetic resonance imaging could be used to explore these relationships in more detail. The influence of surgical revascularization may also be important. Unfortunately, the small sample size precludes a rigorous understanding of cause and effect. Of note, these expert surgeons now exclude patients with an E/A ratio $>2$ from SVR. $^{7}$

Precision cardiovascular medicine and surgery offer the promise of improved outcomes, quality, and cost of therapeutic interventions by deeper data analysis at the individual level. ${ }^{8}$ The responses of individual patients to surgical interventions like SVR may require a more complete understanding of structural cardiac remodeling at the cell, protein, and gene levels. The underlying myocardial characteristics and regulatory pathways for fibrosis and extracellular matrix remodeling for individual patients may strongly influence the results of SVR and other surgical interventions.

We face a growing epidemic of ischemic heart failure. Simple surgical alternatives to heart transplantation and mechanical support devices for these complex patients are welcomed. Fantini and colleagues provide novel information that confirms a role for SVR in improving diastolic dysfunction in selected patients with ischemic and restrictive cardiomyopathy. A more precise understanding of who could benefit from SVR and when this restorative surgery should be performed is needed. 


\section{References}

1. Dor V, Saab M, Coste P, Kornaszewska M, Montiglio F. Left ventricular aneurysm: a new surgical approach. Thorac Cardiovasc Surg. 1989;37:11-9.

2. Anthanasuleas CL, Buckberg GD, Stanley AW, Siler W, Dor V, DiDonato M, et al Surgical ventricular restoration: the RESTORE group experience. Heart Fail Rev. 2004; $9: 287-97$

3. Dor V, Sabatier M, Mentiglio F, Civaia F, DiDonato M. Endoventricular patch reconstruction of ischemic failing ventricle. A single center with 20 years experience. Advantages of magnetic resonance imaging assessment. Heart Fail Rev. 2004;9:269-86.

4. Choi JO, Daly RC, Lin G, Lahr BD, Wiste HJ, Beaver TM, et al. Impact of surgical ventricular reconstruction on sphericity index in patients with ischemic cardiomyopathy: follow-up from the STICH trial. Eur J Heart Fail. 2015;17 453-63.

5. Jones RH, Velazquez EJ, Michler RE, Sopko G, Oh JK, O'Connor CM, et al. Coronary bypass surgery with or without surgical ventricular reconstruction. $N$ Engl J Med. 2009;360:1705-17.

6. Fantini F, Toso A, Menicanti L, Moroni F, Castelvecchio S. Restrictive filling pattern in ischemic cardiomyopathy: insights after surgical ventricular restoration. J Thorac Cardiovasc Surg. 2021;161:651-60.

7. Castelvecchio S, Pappalardo OA, Menicanti L. Myocardial reconstruction in ischemic cardiomyopathy. Eur J Cardiothorac Surg. 2019;55(Suppl 1):i49-56.

8. Califf RM. Future of personalized cardiovascular medicine: JACC state-of-the-art review. J Am Coll Cardiol. 2018;72:3301-9.
See Article page 651.

\section{Commentary: The wisdom of a Nobel laureate and surgical ventricular reconstruction}

\author{
Torsten Doenst, MD
}

\section{All it takes is just "one good experiment."}

$$
\text { -Hans A. Krebs (1900-1981) }
$$

Hans Krebs made this statement when explaining that a convincing treatment effect (he suggested insulininduced glucose uptake of cells) can be witnessed with a single experiment. and that there is little need for endless repetition until statistical significance is reached. In clinical practice, where causal relationships are difficult to establish, such repetition is often needed; however, we may have significant treatment effects that are difficult to explain (as for the survival impact of surgical revascularization $^{1}$ ) or a suggested mechanism that is convincing but for which the treatment effect appears clinically irrelevant (as for volume reduction in surgical ventricular reconstruction $[\mathrm{SVR}]^{2}$ ).

From the Department of Cardiothoracic Surgery, Jena University Hospital-Friedrich Schiller University of Jena, Jena, Germany.

Disclosures: Author has nothing to disclose with regard to commercial support.

Received for publication Oct 21, 2019; revisions received Oct 21, 2019; accepted for publication Oct 21, 2019; available ahead of print Nov 5, 2019.

Address for reprints: Torsten Doenst, MD, Department of Cardiothoracic Surgery, Jena University Hospital-Friedrich Schiller University of Jena, Am Klinikum 1, 07747 Jena, Germany (E-mail: doenst@med.uni-jena.de).

J Thorac Cardiovasc Surg 2021;161:662-3

$0022-5223 / \$ 36.00$

Copyright (c) 2019 by The American Association for Thoracic Surgery

https://doi.org/10.1016/j.jtcvs.2019.10.110

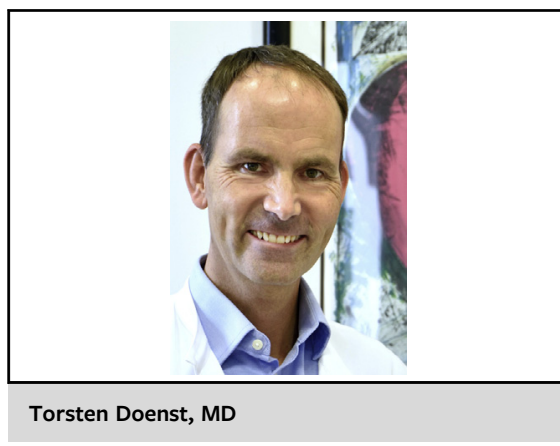

CENTRAL MESSAGE

Surgical ventricular reconstruc-

tion, although ineffective ac-

cording to STICH, may be helpful

in selected patients, possibly

those with classic aneurysms or

high relative posterior wall

thickness.

\section{BUT WHAT IF WE HAVE “ONE GOOD OPERATION"?}

Let us look at the case of a 59-year-old woman, referred for ventricular assist device implantation after myocardial infarction from a left anterior descending coronary artery occlusion and an ejection fraction of $10 \%$ to $15 \%$. She was in New York Heart Association class 4 (Intermacs class 4), with mild mitral regurgitation. Except for the occluded left anterior descending coronary artery, the coronaries looked normal. Her ventricle revealed a large anterior aneurysm, with dyskinesia in the anterior wall, the apex, and significant parts of the interventricular septum. 